\title{
Tiempos de pandemia
}

\author{
Pandemic times \\ Adolfo Cuendis Velázquez* \\ * Editor de la Revista Mexicana de Cirugía Endoscópica.
}

Estimados socios y lectores:

En el cierre de éste, uno de los años más complejos que la historia moderna nos ha dado oportunidad de vivir, donde muchos de nosotros hemos visto caer amigos, familiares, maestros, colegas e infinidad de pacientes ante este terrible mal, me permito invitarlos a una breve reflexión.

Seguramente en ninguno de sus más aventurados sueños médicos era incluida una pandemia como un escenario a enfrentar, y en el que la realidad ha superado con creces la ficción.

Hemos sido testigos del compromiso y vocación del gremio médico ante la enfermedad que, con una fraternidad incansable, ha enfrentado cara a cara la pandemia con el único fin de ver un mejor mañana para los pacientes. Con profunda tristeza, dejamos partir a muchos sin otra opción que seguir luchando con ahínco, viendo pasar los soles y las lunas sin tregua alguna del enemigo.

Cierto es que este catastrófico escenario nos ha permitido analizar también las cosas desde el ojo reflexivo del aislamiento y distanciamiento social, que ha dado el justo peso a las verdaderas prioridades en la vida: Salud, familia y amistad, entre otras.

De igual forma, nos ha hecho ver lo afortunados que fuimos y seremos al volver a las actividades académicas presenciales, que tantos lazos de amistad, aprendizaje y colaboración brindan a nuestra comunidad quirúrgica.

En ese mismo afán, hemos recibido muchos trabajos que estoy seguro disfrutarán leer y queremos compartir en este vigésimo aniversario de la revista, invitándoles a no flaquear y continuar con esfuerzo y entusiasmo, utilizando la oferta de actualización a distancia que se ha adaptado a las circunstancias, a fin de mantener el ritmo en favor de nuestros pacientes.

Convencidos que la resiliencia y la ciencia nos permitirán ver nuevos y mejorados horizontes, muy pronto compartiremos salas y pasillos de los congresos. Mientras tanto, y a la distancia, que el largo brazo de la cirugía nos brinde el fraterno abrazo que hoy falta.

Salud, fuerza y esperanza.

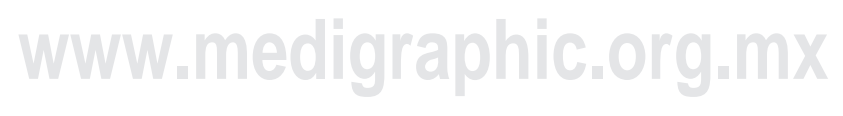

Correspondencia: .Adolfo Cuendis Velázquez. E-mail: drcuendis@gmail.com

Citar como: Cuendis VA. Tiempos de pandemia. Rev Mex Cir Endoscop. 2020; 21 (1): 5. https://dx.doi.org/10.35366/97606 